\title{
Hernia interna de ciego a través del hiato de Winslow
}

\author{
Cecal internal hernia through Winslow's hiatus
}

Ana Nogués P. ${ }^{1}$ José Ramón Oliver G. ${ }^{1}, \mathrm{M}^{\mathrm{a}}$ Soledad Matute N. ${ }^{1}$ y M $\mathrm{M}^{\mathrm{a}}$ Victoria Duque M. ${ }^{1}$

Paciente de 55 años que consulta por dolor abdominal y ausencia de deposiciones en las últimas 48 h. A la exploración física mostraba distensión abdominal. Entre sus antecedentes patológicos figuraban dispepsia posprandial crónica, reparación de válvula mitral y una poliquistosis renal que requirió trasplante renal heterotópico en fosa iliaca izquierda en 2016.

En la TC se observaba una disposición anómala del ciego, localizado en hipocondrio izquierdo, muy dilatado y con abundante contenido fecal, hallazgos sugerentes inicialmente de una volvulación de ciego (Figura 1). Se intervino de urgencia encontrando oclusión intestinal de colon e intestino delgado secundaria a una hernia interna de ciego a través del hiato de Winslow (Figura 2). Se realizó una resección ileocecal más anastomosis ileocólica mecánica. El posoperatorio transcurrió sin complicaciones.

Las hernias internas aparecen en el 0,2\%-0,9\% de los casos de obstrucción intestinal, pero solamente el $8 \%$ de estas, se producen a través del hiato de Wins-

Figura 2. Estrella verde: ciego herniado a través del hiato de Winslow, identificado tras la apertura de la transcavidad de los epiplones.
Figura 1 (1.1, 1.2). TC abdominopélvico. Estrella verde: ciego. Rombo rojo: estómago.

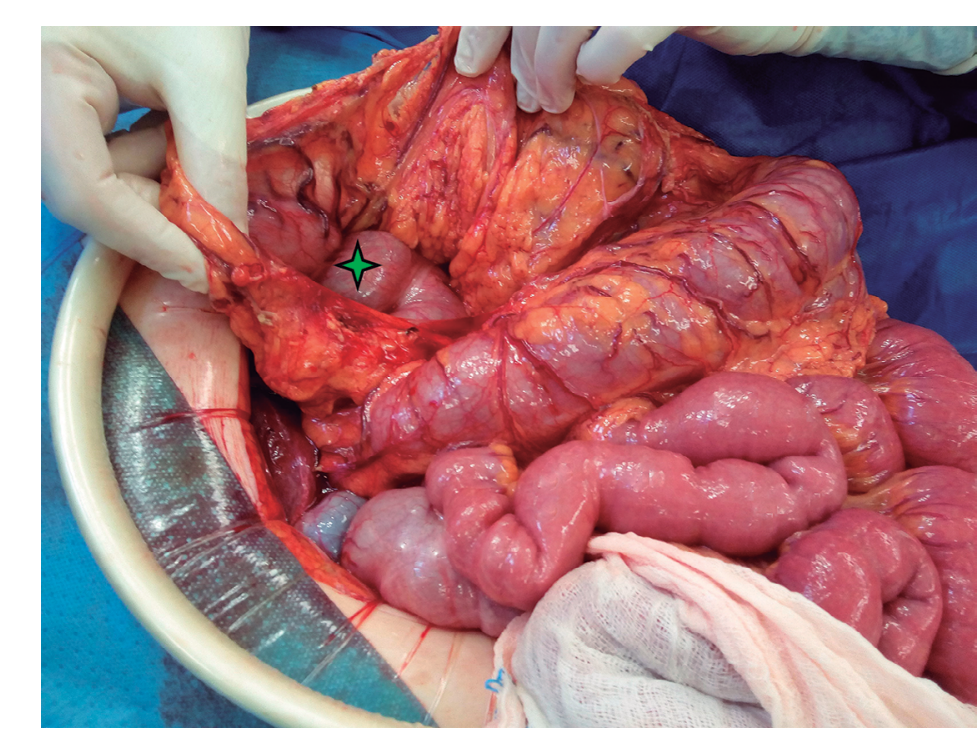

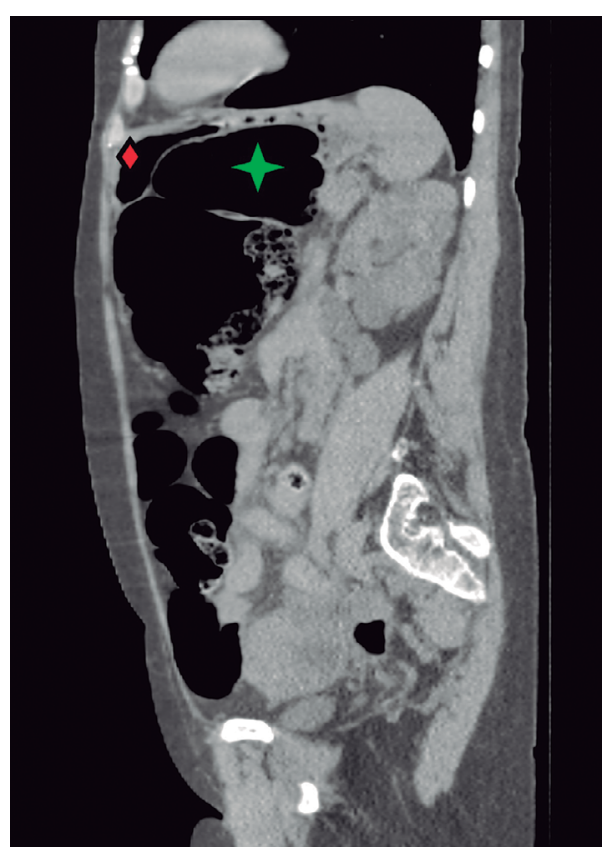

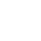

${ }^{1}$ Hospital Universitario Miguel Servet. Zaragoza, España.

Recibido el 18 de agosto de 2018 y aceptado para publicación el 29 de octubre de 2018.

\section{Correspondencia a:} Dra. Ana Nogués P. ananope@gmail.com 
low. Es una entidad muy infrecuente. Los hallazgos característicos del TC incluyen gas y/o líquido en la transcavidad de los epiplones, grasa y vasos mesentéricos posteriores a la vena porta y ciego ausente de su posición anatómica normal.

\section{Agradecimientos}

Agradecemos al Dr. Luis Sarriá (Servicio de Radiología, Hospital Miguel Servet, Zaragoza, España), por la ayuda aportada para la elección de las imágenes presentes en este manuscrito.

\section{Responsabilidades éticas}

Protección de personas y animales. Los autores declaran que para esta investigación no se han realizado experimentos en seres humanos ni en animales.

Confidencialidad de los datos. Los autores declaran que en este artículo no aparecen datos de pacientes.

Conflictos de interés: no hay.

\section{Referencias}

1. Rajeswaran G, Selvakumar S, King C. Internal herniation of the caecum into the lesser sac: an unusual cause of an acute abdomen. Eur Radiol. 2010;20:249-52.

2. Puig CA, Lillegard JB, Fisher JE, Schiller
HJ. Hernia of cecum and ascending colon through the foramen of Winslow. Int J Surg Case Rep. 2013;4:879-81.

3. Iribaren Díaz M, Rivo Vázquez Á, De Castro Parga G, Freiria Barreiros G, Díaz Cardamas P, Iribarren Lorenzo N, et al. Hernia interna a través del hiato de
Winslow asociada a rotación incompleta del intestino medio. Rev Esp Enferm Dig. 2009;101:71-80.

4. Cabrera PA, Mosquera MS, Kadamani A, Sánchez G, Santos JH. Hernia del hiato de Winslow. Rev Colomb Cir. 2015;30:30610. 